Familiar Faces in High School: How Having the Same Peers from Year-to-Year Links to Student

\author{
Absenteeism \\ J. Jacob Kirksey, Ph.D. \\ Assistant Professor \\ College of Education \\ Texas Tech University \\ Jacob.Kirksey@ttu.edu \\ Joseph Elefante, M.A. \\ $\mathrm{Ph}$.D. Student \\ College of Education \\ Texas Tech University
}




\begin{abstract}
Student absenteeism is a persistent concern in K-12 education. Not only are the negative academic and social consequences of excessive absenteeism well documented, but states, districts, and schools are increasingly being held accountable for student attendance. As research indicates that disruptions in students' learning contexts may exacerbate absenteeism, peer consistency shows promise as a force for improving student attendance. This article examines whether having familiar faces, or consistent classmates from one year to the next, influences student attendance. Using four years of administrative data from a small, urban high school district in California, we find that familiar faces are associated with reduced rates of overall absences, chronic absenteeism, and chronic truancy.
\end{abstract}




\section{Familiar Faces in High School: How Having the Same Peers from Year-to-Year Links to Student}

\section{Absenteeism}

The negative impact of poor attendance on students' academic achievement (Authors, 2017; Chang \& Romero, 2008; Easton \& Engelhard, 1982; Gottfried, 2014; Roby, 2004), graduation rates (Author, 2019), engagement, and social adjustment (Gottfried, 2014) is well established. In addition, the United States (U.S.) federal government requires that states report rates of chronic absenteeism (Jordan, 2019). The U.S. Department of Education (ED) collects this data through the Office for Civil Rights, which is then reported every two years as a part of the Civil Rights Data Collection release (Attendance Works, 2020). Further, the Every Student Succeeds Act (ESSA) requires that states choose at least one non-academic metric, or School Quality or Student Success (SQSS) indicator, with which to measure school quality (Every Student Succeeds Act, 2015). As such, 37 states and the District of Columbia have selected chronic absenteeism among their SQSS indicators (Jordan, 2019).

States have adopted several frameworks for incorporating absenteeism into their accountability metrics. As one example, the California Department of Education includes a chronic absenteeism indicator (CA Department of Education, 2019) as part of its CA School Dashboard, a website created "to help parents and educators identify strengths and areas for improvement" (CA Department of Education, 2017). Where the California indicator only reports K-8 absenteeism, Connecticut has included a K-12 accountability measure (Kostyo et al., 2018). As part of that indicator, the state has set a goal of statewide absentee rates to 5\%, emphasizing early prevention (Kostyo et al., 2018). Indiana's system includes an indicator for students who have improved their attendance. The state also rewards schools for having students identified as "model attendees," which can be students with exemplary attendance or those who have shown significant improvement in attendance (Kostyo et al., 2018).

As absenteeism becomes a more ubiqutous accountability metric, schools and policymakers across the country are looking for malleable ways of improving student attendance at the school-level, though these interventions or programs certainly vary with respect to their financial cost to schools. For example, fairly robust research notes the importance of reliable school transportation in ensuring students can get to school (Authors, 2021a ; Cordes \& Schwartz, 2019; Gottfried, 2017). Other programs that research suggests improving student attendance include breakfast programs that include free meals (Schwartz \& Rothbart, 2020) or meal service during the school day (Authors, 2021b), center-based childcare (Gottfried, 2015), mentoring programs (Childs \& Grooms, 2018), therapy (Gandy \& Schultz, 2007), parent-focused text-messaging programs (Smythe-Leistico \& Page, 2018), 
and school-to-home mailers (Robinson et al., 2018). Strategies aimed at increasing parent input in school decision making, overall parent involvement, and building trusting relationships between parents and teachers also show promise in improving student attendance (Lenhoff \& Pogodzinski, 2018).

Following suit, we examine the influence that a students' peers may exert on their attendance behaviors. Surprisingly, extant previous research has only focused on the influence of peers on elementary students' attendance outcomes. For example, Authors (2018) examined the role of having "familiar faces," or being in class with many of the same students as the previous year, on elementary student absenteeism. The authors found that having a greater proportion of familiar faces corresponded to moderate declines in the number of days students were absent as well as their likelihood of chronic absenteeism. To our knowledge, no research has examined whether peer or teacher familiarity connects to attendance for high school students, a grade span that is at a starkly different developmental point in time compared to elementary students. Focusing on students in high school, we extend Authors' (2018) work and consider how having "familiar faces", or having some of the same peers from year to year, might link with reductions in student absenteeism. The segmented class structure at the secondary level also allows for another layer of analysis by course characteristics- e.g., whether a course is a core academic subject and the time of day a student is enrolled in the course - and whether the relationship between familiar faces and student attendance differs by these course characteristics.

Specifically, we ask the following research questions:

1. Is having more familiar faces in a student's course associated with fewer absences in that specific course?

2. Does having more familiar faces in all courses associate lower likelihood of chronic absenteeism, truancy, or chronic truancy?

3. Do these associations differ based on course type?

\section{Empirical Background}

As defined above, we operationalize the term "familiar faces" to focus on peer stability, or having the same peers from year to year. In that respect, much of the empirical research related to familiar faces involves experiments in looping, or keeping groups of students and teachers together over multiple years, as a way to increase students' engagement and achievement level in school (LAB at Brown University, 1997). New York City school leader Deborah Meier famously introduced looping in her school in the 1970s, and the concept has been attempted sparingly by some other - mostly private - schools in the following decades (Nitecki, 2017). Among the noted 
benefits of looping are: 1) increased instructional time, as less time is required to form connections between teachers and students; 2) more comprehensive teacher knowledge of student strengths and limitations; 3) improved long-term student-teacher and student-student relationships; 4) a level of social trust and comfort that encourages enhanced social construction of learning and an environment of risk-taking; and 5) a stronger sense of community among students, teachers, and families (LAB at Brown University, 1997).

Research in this regard has shown mixed but generally positive results. Cistone and Shneyderman (2004), in a large urban Florida district of 26 elementary schools, found significant gains in achievement on both standardized math and reading tests for looped students during the 1999-2000 school year. Bogart (2002) documented equally significant results for $4^{\text {th }}$-graders in four East Tennessee school districts in 1999-2000. Gregory (2009) found similarly impressive results for both math and reading scores with 300 Georgia middle school students in the 2007-2008 school year. Langmuir (2014), looking at a sample of $8511^{\text {th }}$ - and $12^{\text {th }}$-grade New Jersey students in the 2008-2009 school year, observed gains in reading scores but no significant improvement in math scores. Interestingly, in a study of 206 looped Mississippi middle school students in 2008-2009, Franz et al. (2010) noted significant improvement in math scores for females but none for males.

Gregory (2009) also found a positive association between looping and students' social outcomes like selfreported loyalty, belonging, and self-confidence, but no discernable reduction in discipline referrals. Cistone and Shneyderman (2004) saw an improvement in student attendance in their looped sample and reported positive impressions of the practice from the participating teachers and administrators. The Attleboro, Massachusetts School District found that, when looping students in grades 1-8, attendance improved by over 5\%, grade retention decreased by $43 \%$, discipline referrals and suspensions declined, special education referrals dropped by $55 \%$, and even staff attendance markedly improved (Grant, 2000).

Some researchers have looked at peer and teacher familiarity and consistency more broadly. Nitecki (2017) found that peer familiarity among preschool students enhanced teacher-parent and teacher-student relationships, increased instructional time, and improved student behavior. Similarly, Hill and Jones (2018) found that teacherstudent familiarity over consecutive years improved $3^{\text {rd }}-5^{\text {th }}$ grade students' performance on end-of-grade math tests.

\section{Conceptual Framework}

Research has shown that children's behavior is often affected by their peers. For example, previous research has shown that peer absenteeism is linked to a student's own absenteeism in the same year (Author et al., 
2020). Also, certain peer experiences, like negative relationships (Ladd, 1990), peer victimization (Espelage et al., 2013), or frequently shifting social conditions (Anderson et al., 2000), can result in school refusal behaviors. These include skipping specific classes or times of the school day, expressing emotional problems like anxiety, fatigue, or suicidal behavior, and complaining of physical symptoms such as stomach pain, headaches, or nausea to avoid attending school (Kearney \& Bensaheb, 2006).

With this in mind, there is reason to believe that the consistency and stability vis-à-vis familiar faces may have a positive effect on students' school attendance. Having some peer consistency may foster a stable learning context for students, which can improve student attendance by avoiding disruptive schooling experiences. For example, Berndt et al. (1999) found that students that were able to maintain stable peer relationships with classmates throughout the transition into middle school enjoyed higher levels of sociability and leadership. Berndt and Keefe (1995) demonstrated that stable peer relationships have a positive influence on students' adjustment to school. These consistent peer relationships result in more stable learning contexts, which tend to improve student engagement in school (Juvonen et al., 2012). Students with consistent peer relationships are better liked and perceived by their teachers as more socially well adjusted (Ladd \& Price, 1987). Further, consistent peer relationships positively affect social and academic engagement, which are correlated to improved school attendance (Broadhurst et al., 2005).

This framework suggests that familiar faces may have an indirect positive effect on attendance. As Anderson et al. (2000) have demonstrated the negative effects of consistently changing school contexts has on student adjustment and engagement, it stands to reason that familiar faces could potentially mitigate those effects. Neckerman (1996) showed that, when a classroom of students are promoted together to the next grade level, 55\% of the social groups remained stable, as opposed with to just $7 \%$ in other classes. Paired with the findings of Berndt and Keefe (1995), this suggests that students in classrooms with more familiar faces may adjust better to school transitions and, therefore, be more engaged socially and academically. Juvonen (2007), in her proposed framework for 'maximizing students' engagement in middle school, recommends keeping a group of students together with the same teacher across consecutive years, arguing that the aim of the practice is to "enhance the continuity of students' educational experience and foster closer connections between teachers and their students” (p. 205).

As the current body of research in this field targets the elementary level, we look specifically at the effect of familiar faces in high school contexts. According to the 2015-16 Civil Rights Data Collection release, chronic absenteeism rates in the U.S. are the highest at the high school level (U.S. Department of Education, 2019). In 
particular, the transition into high school has been shown to disrupt student engagement, which is associated with poor attendance behaviors throughout high school (Benner \& Wang, 2014). Consistent peers may provide much needed stability during high school, where learning contexts change more frequently and rapidly than at any previous level of schooling.

\section{Method}

\section{Data}

This study uses administrative data provided by a high school district consisting of three traditional public high schools that serve a small, urban area of California. Data were obtained directly from the district's central office following approval from the Institutional Review Board. Information was provided on student demographics, course information, discipline, and absenteeism, and student records were linked across datasets using blind identifiers.

We leveraged four years of data of students in $9^{\text {th }}-12^{\text {th }}$ grades from the 2013-14 to the 2016-17 school year. However, as our key focus is how having familiar faces relates to student absenteeism, our analytic sample consisted of students over three years from 2014-15 to 2016-17, with the 2013-14 year dropped given that we do not know students' course placements in the previous school year. Additionally, we limited our sample to students who were enrolled the entire school year, as students who transferred or dropped out of school would have less opportunity to be exposed to familiar faces and the district stops tracking their absences as soon as they leave the district. Finally, we restricted our sample to students with complete course, attendance, and demographic information, which were necessary to construct the key variables of interest. As such, the final analytic sample consists of 17,465 student-byyear observations over the three school years.

As seen from Table 1, the district serves a predominantly Latinx (81\%), English learner (61\%), and free or reduced-priced eligible (71\%) population of students. Other student characteristics include: $9 \%$ of students received special education services via an Individualized Education Program (IEP), 14\% of students were considered migrant, $4 \%$ of students were considered homeless. As far as incidents of school discipline, the average number of suspensions was about 0.03 for both in school and out of school suspensions, and even a smaller portion of students received a referral to juvenile court.

\section{Outcomes}

<Insert Table 1 about here> 
A key advantage of working with this particular dataset is that absenteeism was reported for students by classroom (i.e., period-level logs of attendance), which allows us to examine the impact of familiar faces on absenteeism by capitalizing on variation in familiar faces as well as variation in absenteeism across class periods for students. With this level of detail, we constructed two sets of absenteeism outcome measures.

The first set of outcome measures were at the classroom-level. From the attendance logs, we calculated the number of days a student was absent for a particular class (e.g., a student's $1^{\text {st }}$ period Algebra II in 2015-16). We divided this number by the total number of days a student could have attended this class. This creates the first outcome of interest, which is a student's classroom-specific average daily absence rate. Similarly, we also separated this outcome into two additional variables by divided a student's absences into excused and unexcused, creating the average daily excused absence rate and the average daily unexcused absence rate. Again, these outcomes vary across a student's courses, as a student could miss only portions of a particular day of school.

The second set of outcome measures were at the student-by-year level, as these represent clearly defined policy constructs of student absenteeism that are embedded in the district's accountability metrics. The first outcome is a binary indicator for chronic absenteeism, which is defined as a student having missed $10 \%$ or more of the school year. Consistent with the definition provided in California's ESSA Consolidated State Plan policy, we considered a student to be chronically absent if they missed an aggregated total of $10 \%$ or more of the available class periods they could have attended, regardless of which class(es) a student missed. Next, we constructed another binary variable indicating whether a student was considered truant, which the district defines as having 21 or more unexcused absences, which is three whole days of school for students with a full schedule. Lastly, similar to our measure of chronic absenteeism, we constructed a measure of chronic truancy, defined as missing $10 \%$ or more of the days enrolled each year via unexcused absences.

\section{Familiar Faces}

The key predictor variable was the proportion of a student's class that was familiar faces. To construct this variable of interest, we relied on the blind identifiers of the teacher, course codes from the students' transcripts, and the period of class. This created a unique identifier for a single classroom of students. Using these identifiers, we calculated the number of students who were in a student's current classroom who were also in a class with the student in the previous school year. After calculating the number of familiar faces, we divided this number by the 
number of students in the student's current classroom. This created the percentage of familiar faces in the student's class.

\section{Covariates}

Our analyses, described below, account for time-invariant observed and unobserved confounding variation at the student and classroom level. Therefore, we could only include covariates that varied within a student's classroom. Using the same data provided at the student-level displayed in Table 1, we calculated new classroomlevel characteristics (e.g., the number of peers eligible for free or reduced-priced lunch). Then, we subtracted a student's own characteristics from this aggregate to create a peer-level variable. Finally, we divided these peer-level characteristics by the number of peers to create percentages for each demographic characteristic that varies by student within the classroom based on their own student-level characteristics.

\section{Analysis}

To examine the influence of having more familiar faces on classroom-specific student absenteeism rates, we employed the following OLS regression baseline model:

$$
A_{i j k t}=\beta_{0}+\beta_{1} F F_{i j k t}+\beta_{2} X_{i j i t}+\delta_{i}+\delta_{j}+\varepsilon_{i j k t}
$$

where $A$ is the absence outcome for student $i$ in classroom $j$ (i.e., a teacher's $6^{\text {th }}$ period algebra class) in school $k$ in year $t$. This baseline model was employed to examine the first three classroom-level outcomes as described above: overall absence rate, unexcused absence rate, and excused absence rate. The variable of interest is $F F$, which represents the percentage of a student's classroom that is comprised of familiar faces, or students with whom the student shared at least one class in the previous school year. The time-varying peer-level covariates are represented by $X$. The model also includes student $\left(\delta_{i}\right)$ and classroom $\left(\delta_{j}\right)$ fixed effects, which represent binary indicators for every student and unique classroom in the dataset with one student and one classroom left out as the reference group. These fixed effects hold constant all between student and between classroom-level variation, a strategy similar to that of hierarchical linear modeling but one that requires fewer pre-estimation assumptions (Hoxby, 2000). This means that the estimated effect of having familiar faces is informed by two primary sources of variation. The first is how a student's attendance varies across classrooms within one year and across classrooms over time as the proportion of familiar faces differs. The second is how a student's attendance compares to their peers' attendance in the same classroom compared to the differing proportion of familiar faces each student has based on their previous classrooms. Lastly, we cluster the standard errors at the classroom-level. 
To examine how familiar faces links with students' likelihood of being chronically absent, truant, or chronically truant, we employ the following linear probability model:

$$
A_{i k t}=\beta_{0}+\beta_{1} F F_{i k t}+\beta_{2} X_{i i t}+\delta_{i}+\delta_{k}+\varepsilon_{i k t}
$$

where $A$ represents each of the binary absence outcomes for student $i$ in school $k$ in year $t$. All previous classroomlevel explanatory variables, including familiar faces and peer characteristics, are now constructed as averages across a student's courses and aggregated to the student-by-year level. Recall this student-by-year level of analysis is consistent with the district's classification policy of chronic absence, truancy, and chronic truancy. Similar to the previous model, this approach incorporates student fixed effects to account for student-level confounding variation. We replace classroom fixed effects with school fixed effects and include additional fixed effect indicators for gradelevel and year. Standard errors are clustered at the school-level.

\section{Differences by Course Type}

We examined whether familiar faces might connect to student absenteeism differently based on two specific course characteristics. First, we examined whether the relationship between familiar faces and absenteeism rates different based on whether the student was in an academic course (i.e., math, English, science, or social studies) or a non-academic course. Second, we examined whether the influence of familiar faces on absences differed based on time of day. For each of these additional lines of inquiry, we employed model 1 separately for academic and non-academic courses as well as for first period, middle periods (periods 2-6), and the last period of the school day (period 7), allowing a student's familiar faces and absences to vary by classroom.

\section{Results}

\section{Research Question 1}

Table 2 presents coefficients from our empirical specification outlined in model 1 above, where we tested how the percentage of familiar faces in a classroom related to a student's absence rates for that classroom. Coefficients represent marginal changes in student's overall absence rates, unexcused absence rates, and excused absence rates for each unit shift in the predictor variable, holding all else constant. Since all independent variables represent classroom-level percentages, a one unit change in familiar faces, for example, would mean that $100 \%$ of peers in the student's classroom are familiar faces. Standard errors are presented below coefficients in parentheses.

The first row of Table 2 presents the key coefficients of interest, which represent the changes to students' absence rates based on the proportion of familiar faces in their classroom. As seen from Table 2, it appears that 
increases in familiar faces is associated with declines in all three measures of student absence. As seen in column 1, when considering overall absence rates, if a student had $100 \%$ familiar faces in their classroom, their overall absence rates in that classroom tended to decline by 4.2 percentage points. Similarly, if a student had $100 \%$ familiar faces in their classroom, their unexcused absence rates in that classroom tended to decline by 3.6 percentage points. Notably, the estimates are much lower when considering the influence of familiar faces on excused absence rates, as $100 \%$ familiar faces corresponds to a decline of just 0.6 percentage points in the student's excused absence rate.

While coefficients represent shifts to absence rates based on having $100 \%$ familiar faces, a more realistic interpretation would be to consider how a student's absence rates might change if they had $25 \%$ more familiar faces. In that case, we would expect students' absence rates to change by 1 percentage point for every $25 \%$ of familiar faces they have in their classroom. Recall these estimates are statistically significant even after incorporating extensive fixed effects at the student and unique classroom levels.

\section{Research Question 2}

Table 3 presents results for the student-by-year level analyses, where we consider how the average percentage of familiar faces a student had across their courses in a year related to their likelihood of being chronically absent, truant, or chronically truant. As with Table 2, coefficients in Table 3 represent marginal changes in the likelihood of chronic absenteeism, truancy, and chronic truancy based on having $100 \%$ familiar faces across courses. As seen from Table 3, we observe a small but statistically significant relationship between increases in familiar faces and chronic absenteeism or chronic truancy. Specifically, if $100 \%$ of a students' classmates were familiar faces, they would have 3.3 and 4.4 percentage points lower likelihood of chronic absenteeism and chronic truancy, respectively. Considering a realistic shift of a $25 \%$ increase in familiar faces, this shift would relate to a roughly a $1 \%$ point decline in the likelihood of chronic absenteeism and chronic truancy. Note, we do not observe a statistically significant relationship between having familiar faces and likelihood of truancy.

\section{Research Question 3}

Our last research question asks whether the relationship between increases in familiar faces and absence outcomes differs depending on course type. Based on available data for our study, we examined two course characteristics: academic versus non-academic courses and time a day when a student was enrolled in a course. Table 4 illustrates differences based on these two characteristics. Columns 1 and 2 illustrate results showing the marginal effects of having familiar faces and overall absence rates for academic and non-academic courses, 
respectively. Columns 3, 4, and 5 display results by restrict the sample to students' first period of the day, last period of the day, and the middle periods of the day.

<Insert Table 4 about here>

With regard to academic versus non-academic differences, results in Columns 1 and 2 of Table 4 indicate that having more familiar faces appears to be linked to reductions in overall absence rates in both academic and nonacademic courses, though this relationship is slightly more elevated in non-academic courses. That is, our estimates suggest that having $100 \%$ familiar faces appears to link to 5.26 percentage points decline in overall absence rates in non-academic courses compared to a 3.49 percentage points decline in academic courses. Using a more pragmatic hypothetical, a $25 \%$ increase in the number of familiar faces links to a decline in 1.32 percentage points in overall absence rates in non-academic courses compared to a 0.87 percentage points decline in academic courses.

Turning attention to the last three columns of Table 4, our findings suggest that an increase in familiar faces is linked to declines in absence rates in the period 1, the first period of the day, and periods $2-6$, the middle periods of the day. While the coefficients in columns 3 and 5 are statistically different in terms of magnitude, practically, difference in magnitude is quite small. On the other hand, we do not find that an increase in familiar faces associates with better or worse absence rates in period 7 , or the last period of the school day.

\section{Other Exploratory Analyses}

While the motivation for this study is guided by conceptual and empirical understandings of how having familiar faces might foster better attendance behaviors, we also explored whether having familiar faces might also be linked with other measures of student engagement, such as student suspensions ${ }^{1}$. As school discipline was reported at the student-by-year level and disciplinary actions were not necessarily tied to unique classrooms, Table 5 presents associations between student-by-year averages of familiar faces across courses and suspensions. Note this model uses the empirical specification outlined in Eq. 2 above.

\section{<Insert Table 5 about here>}

As seen from Table 5, we do not find evidence that having familiar faces was linked to the total number of suspensions. However, when breaking out total suspensions into two separate outcomes, the total number of inschool and out-of-school suspensions, we show that an increase in familiar faces was linked to small declines in the

\footnotetext{
${ }^{1}$ For transparency, we report these results in hopes that future research might build on these exploratory analyses guided by confirmatory hypotheses (Gehlbach \& Robinson, 2018, 2021).
} 
total number of in-school suspensions students received. We do not find evidence that familiar faces related to outof-school suspensions.

\section{Discussion}

This study examines whether familiar faces, or consistent peers year-over-year, are associated with reductions in student absenteeism. More specifically, we look at the relationship between the percentage of familiar faces in a given course with a student's rate of absence in that course. We also explore how a student's average percentage of familiar faces per course correlates with chronic absenteeism, truancy, or chronic truancy. Our findings demonstrate that familiar faces can have a modest, negative association with absenteeism rates. For example, in the context of our findings, an increase of $20 \%$ familiar faces in a given course would be associated with a 0.84 percentage point decrease in overall absence rate in that course. As over $26 \%$ of the students in our sample had an average of $50 \%$ or fewer familiar faces in their courses, increasing students' number of familiar faces by $20 \%$ might be feasible in many cases.

This association is most pronounced for unexcused absences, which is noteworthy given that prior research has shown that unexcused absences are more predictive of declines in academic outcomes for students (Gottfried, 2009). This is likely due to the connection between unexcused absences and students' lack of academic and social engagement (Finn \& Zimmer, 2012). Similarly, we would not expect familiar faces to have much influence on excused absences, which are often for medical or family reasons, although students may fake illness or even experience physical or emotional symptoms as a way to avoid attending school (Arthurs et al., 2014). Given that framing, the disproportionate link of familiar faces with unexcused versus excused absence rates -3.639 to 0.577 is encouraging and fits with prior research.

We find a small but significant link between familiar faces and chronic absenteeism and chronic truancy. The weakness of this association relative to overall absenteeism is unsurprising given the magnitude of the association between familiar faces and absenteeism rates. The example above is illustrative of this phenomenon. A 0.84 percentage point decrease in absenteeism rates, although significant, is not enough to impact the chronic absenteeism or truancy of students who have absences rates far beyond the chronic absenteeism and truancy thresholds. For example, in our data set, over $12 \%$ of students were missing at least $50 \%$ of their classes. Also, it is important to remember that familiar faces have a much smaller association with excused absence rates, which also contribute to chronic absenteeism and chronic truancy. Another possible explanation for the relatively small 
reduction in chronic absenteeism and truancy associated with familiar faces is that peer familiarity may simply mean less to chronically absent and truant students. Students who miss substantial amounts of school may have a weaker connection to their peers, despite sharing class with them over multiple years.

We also examine the link between familiar faces and absence rates based on course type and time of day. Specifically, we look at the link between absence rates in academic courses - math, ELA, science, social studies versus non-academic courses. The results are significant in both cases, although the association is over 50\% larger for non-academic courses -5.261 to 3.489. Although it is impossible to discern from the data we have, it is possible that the higher level of peer socialization intrinsic to non-academic courses accounts for the stronger influence of familiar faces on student attendance in those classes. As far as when in the day the course takes place, familiar faces have nearly the same association with absence rates for first period as the middle five periods of the day. Interestingly, they have no significant association with absence rates for the seventh and last period of the school day. It is possible that, although familiar faces may succeed in getting students to come to school more often, we are most likely to observe those benefits at the beginning of the day (Authors, in press). There are more reasons unrelated to familiar faces that a student might miss the later part of the school day - for example, athletics or medical appointments.

This study's framework is centered on the impact of peers on student attendance. Given this framing, it is noteable that familiar faces are associated with improvement in nearly every attendance metric. Although we do not have access to data relative to the nature of specific relationships among peers, this study is aligned with existing literature on the influence of peers on students' school engagement. Familiar faces represent consistency. which may explain their positive influence on attendance. That consistency, and its implications for stronger and more durable peer networks, may provide much needed stability amidst the many changes in students' learning contexts, like school transitions, grade advancement, and new teachers and classmates (Juvonen, 2007).

\section{Implications}

These results suggest that familiar faces are a malleable, low-cost, school-level factor that may improve student attendance. As attendance becomes more entrenched as a metric of student engagement and school accountability, schools are further incented to find levers for improving attendance. School leaders and policymakers may increasingly look to strategies that emphasize familiarity, consistency, and stability, which 
research indicates can have a positive impact on student engagement and school connectedness. School leaders stand to gain by collecting more and better data in these areas - including familiar faces.

These findings are of particular interest given the demographics of our sample. Familiar faces are associated with improved attendance rates and reduced chronic absenteeism and chronic truancy in our district, which has high levels of Latinx students, English learners, and free or reduced lunch. As U.S. schools become increasingly diverse, practitioners are seeking ways to engage students from varied cultural, linguistic, and socioeconomic backgrounds, who are often marginalized. Our findings indicate that familiar faces may be a valuable student engagement strategy when working with diverse student populations.

This article adds to the literature suggesting that scheduling matters for students' attendance outcomes. It may not be possible in every case to ensure that all students have a requisite percentage of familiar faces. That said, there are ways for to districts to embed parameters within the processes of assigning students to certain classes, teachers, or cohorts of students, closing and merging schools, or even redistricting school communities to include elements of familiarity. For example, Krauss et al. (2013) recommend an integer programming model for managing placement constraints in student scheduling. There is potential to include a familiar faces parameter in that kind of a model.

There is also the possibility of implementing looping programs, if even just for certain grade levels or categories of students. As the literature suggests, the familiarity and consistency inherent in looping is associated with improved academic outcomes (Bogart, 2002; Cistone \& Shneyderman, 2004; Franz et al., 2010; Gregory, 2009; Langmuir, 2014), social competency (Gregory, 2009), discipline (Grant, 2000), grade advancement (Grant, 2000), perceptions of school (Cistone \& Shneyderman, 2004), and attendance (Cistone \& Shneyderman, 2004; Grant, 2000). Familiar faces may offer an opportunity to provide some of the benefits associated with familiarity and consistency without implementing a broad-based looping program. School administrators may also want to consider familiar faces when making tracking decisions. These findings also hold implications for parents, who may want to advocate for familiar faces for their children.

\section{Limitations}

For this study, we exclusively used administrative data. As such, we have no insight into the nature of the students' peer relationships. Research suggests that, in addition to the quantity, the type or quality of these relationships matters impact students' adjustment to and engagement in school (e.g., Ladd, 1990). We also have no 
data on the students' elementary or middle school familiarity - for example, the number of familiar faces or the nature of those relationships.

This study was limited to one single school district over a finite, four-year time period. This limits the generalizability of these findings to other contexts. Additionally, although we were able to account for both observed and unobserved selection biases, this study was not designed as either a controlled experiment or quasiexperiment. Given these limitations, we stop short of making any causal inferences.

\section{Recommendations for Future Research}

This is one of relatively few studies that attempts to explain the effects of familiar faces outside the scope of broader interventions. Familiar faces are an embedded aspect of many programs like looping and tracking, but there is little research on their intrinsic benefit. More research should be done on the effects of familiar faces in isolation, including experimental or quasi-experimental designs.

The sample for this study was restricted to one school district over four years. Future research on familiar faces should look to expand the breadth of research to include more districts. Researchers should work to include districts from diverse geographic areas which serve different communities and student populations. Further, it may be helpful to examine familiar faces over longer periods of time.

Future work can incorporate qualitative data on the nature of students' relationships and how different types of relationships interact with familiar faces. Further, researchers can explore the intersection between familiar faces and students' background characteristics. In addition to familiar peer faces, there may also be knowledge gained from looking at student/teacher familiarity. Both peer and student-teacher familiar faces could be examined over multiple years, as opposed to year-over-year, as we did in this study. This is where the unique nature of music ensembles or athletics may be particularly instructive, as students in those courses and activities often work with the same directors, coaches, and student cohorts for several years in a row. 


\section{References}

Authors. (2018).

Author. (2019).

Authors. (2021a).

Authors. (2021b).

Authors. (In press).

Anderson, L. W., Jacobs, J., Schramm, S., \& Splittgerber, F. (2000). School transitions: Beginning of the end or a new beginning? International Journal of Educational Research, 33(4), 325-339.

https://doi.org/10.1016/S0883-0355(00)00020-3

Arthurs, N., Patterson, J., \& Bentley, A. (2014). Achievement for students who are persistently absent: Missing school, missing out? Urban Review, 46, 860-876. https://doi.org/10.1007/s11256-014-0307-4

Attendance Works. (2020). Federal policy. https://www.attendanceworks.org/policy/federal-policy/

Benner, A. D., \& Wang, Y. (2014). Shifting attendance trajectories from middle to high school: Influences of school transitions and changing school contexts. Developmental Psychology, 50(4), 1288-1301. https://doi.org/10.1037/a0035366

Berndt, T.J, \& Keefe, K. (1995). Friends' influence on adolescents' adjustment to school. Child Development, 66(5), $1312-1329$.

Berndt, Thomas J., Hawkins, J. A., \& Jiao, Z. (1999). Influences of friends and friendships on adjustment to junior high school. Merrill-Palmer Quarterly, 45(1), 13-41.

Bogart, V. S. (2002). The effects of looping on the academic achievement of elementary school students [East Tennessee State University]. https://dc.etsu.edu/cgi/viewcontent.cgi?referer=https://search.yahoo.com/\&httpsredir=1\&article=1864\&contex $\mathrm{t}=$ etd

Broadhurst, K., Paton, H., \& May-Chahal, C. (2005). Children missing from school systems: Exploring divergent patterns of disengagement in the narrative accounts of parents, carers, children and young people. British Journal of Sociology of Education, 26(1), 105-119. https://doi.org/10.1080/0142569042000292743

CA Department of Education. (2017). About accountability. https://www.caschooldashboard.org/about/accountability 
CA Department of Education. (2019). Chronic absenteeism indicator.

https://www.cde.ca.gov/ta/ac/cm/documents/chronicabsenteeism.pdf

Chang, H. N., \& Romero, M. (2008). Present, engaged, and accounted for: The critical importance of addressing chronic absence in the early grades. https://www.nccp.org/wp-content/uploads/2008/09/text_837.pdf

Childs, J., \& Grooms, A. A. (2018). Improving school attendance through collaboration: A catalyst for community involvement and change. Journal of Education for Students Placed at Risk, 23(1-2), 122-138. https://doi.org/10.1080/10824669.2018.1439751

Cistone, P., \& Shneyderman, A. (2004). Looping: An empirical evaluation. International Journal of Educational Policy, Research, and Practice: Reconceptualizing Childhood Studies, 5(1), 47-61.

Cordes, S. A., \& Schwartz, A. E. (2019). Does pupil transportation close the school quality gap? Evidence from New York City. https://www.urban.org/research/publication/does-pupil-transportation-close-school-quality-gap

Easton, J. Q., \& Engelhard, G. (1982). A longitudinal record of elementary school absence and its relationship to reading achievement. The Journal of Educational Research, 75(5), 269-274. https://doi.org/10.1080/00220671.1982.10885393

Espelage, D. L., Hong, J. S., Rao, M. A., \& Low, S. (2013). Associations between peer victimization and academic performance. Theory into Practice, 52(4), 233-240. https://doi.org/10.1080/00405841.2013.829724

Every Student Succeeds Act, (2015). https://www.congress.gov/114/plaws/pub195/PLAW-114pub195.pdf

Finn, J. D., \& Zimmer, K. S. (2012). Student Engagement: What Is It? Why Does It Matter? In S. L. Christenson, A. L. Reschly, \& C. Wylie (Eds.), Handbook of Research on Student Engagement (pp. 97-131). Springer. https://doi.org/10.1007/978-1-4614-2018-7

Franz, D. P., Thompson, N. L., Fuller, B., Hare, R. D., Miller, N. C., \& Walker, J. (2010). Evaluating mathematics achievement of middle school students in a looping environment. School Science and Mathematics, 110(6), 298-308. https://doi.org/10.1111/j.1949-8594.2010.00038.x

Gandy, C., \& Schultz, J. L. (2007). Increasing school attendance for $k-8$ students: A review of research examining the effectiveness of truancy prevention programs.

Gehlbach, H., \& Robinson, C. D. (2018). Mitigating illusory results through preregistration in education. Journal of Research on Educational Effectiveness, 11(2), 296-315.

Gehlbach, H., \& Robinson, C. D. (2021). From old school to open science: The implications of new research norms for educational psychology and beyond. Educational Psychologist, 56(2), 79-89. 
Gottfried, M. A. (2014). Chronic absenteeism and its effects on students' academic and socioemotional outcomes. Journal of Education for Students Placed at Risk, 19(2), 53-75. https://doi.org/10.1080/10824669.2014.962696

Gottfried, M. A. (2015). Can center-based childcare reduce the odds of early chronic absenteeism? Early Childhood Research Quarterly, 32(3), 160-173. https://doi.org/10.1016/j.ecresq.2015.04.002

Gottfried, M. A. (2017). Linking getting to school with going to school. Educational Evaluation and Policy Analysis, 39(4), 571-592. https://doi.org/10.3102/0162373717699472

Grant, J. (2000). In the Loop. American Association of School Administrators. https://www.aasa.org/schooladministratorarticle.aspx?id=14482

Gregory, B. S. (2009). The impact of looping on academic and social experiences of middle school students. Walden University.

Hill, A. J., \& Jones, D. B. (2018). A teacher who knows me: The academic benefits of repeat student-teacher matches. Economics of Education Review, 64, 1-12. https://doi.org/10.1016/j.econedurev.2018.03.004

Jordan, P. (2019). Attendance playbook: Smart strategies for reducing chronic absenteeism. https://www.futureed.org/attendance-playbook/

Juvonen, J. (2007). Reforming middle schools: Focus on continuity, social connectedness, and engagement. Educational Psychologist, 42(4), 197-208. https://doi.org/10.1080/00461520701621046

Juvonen, J., Espinoza, G., \& Knifsend, C. (2012). The role of peer relationships in student academic and extracurricular engagement. In S. L. Christenson, A. L. Reschly, \& C. Wylie (Eds.), Handbook of research on student engagement (pp. 387-401). Springer.

Kearney, C. A., \& Bensaheb, A. (2006). School absenteeism and school refusal behavior: A review and suggestions for school-based health professionals. In Journal of School Health. https://doi.org/10.1111/j.17461561.2006.00060.x

Kostyo, S., Cardichon, J., \& Darling-Hammond, L. (2018). Making ESSA's equity promise real: State strategies to close the opportunity gap - Eliminating chronic absenteeism. https://learningpolicyinstitute.org/product/essaequity-promise-absenteeism-brief

Krauss, B., Lee, J., \& Newman, D. (2013). Optimizing the assignment of students to classes in an elementary school. INFORMS Transactions on Education, 14(1), 39-44. https://doi.org/10.1287/ited.2013.0111 
LAB at Brown University. (1997). Looping: Supporting student learning through long-term relationships. In Themes in Education. https://www.brown.edu/academics/education-alliance/sites/brown.edu.academics.educationalliance/files/publications/looping.pdf

Ladd, G. W. (1990). Having friends, keeping friends, making friends, and being liked by peers in the classroom: Predictors of children's early school adjustment? Child Development, 61(4), 1081-1100.

Ladd, G. W., \& Price, J. M. (1987). Predicting children's social and school adjustment following the transition from preschool to kindergarten. Child Development, 58(5), 1168-1189.

Langmuir, L. (2014). An exploratory investigation of looping high school math and English and student achievement. Rowan University.

Lenhoff, S. W., \& Pogodzinski, B. (2018). School organizational effectiveness and chronic absenteeism: Implications for accountability. Journal of Education for Students Placed at Risk, 23(1-2), 153-169. https://doi.org/10.1080/10824669.2018.1434656

Neckerman, H. J. (1996). The stability of social groups in childhood and adolescence: The role of the classroom social environment. Social Development, 5(2), 131-145. https://doi.org/10.1111/j.1467-9507.1996.tb00076.x

Nitecki, E. (2017). Looping and attachment in early childhood education: How the applications of epigenetics demand a change. Journal of the Scholarship of Teaching and Learning, 17(2), 85-100. https://doi.org/10.14434/josotl.v17i2.20840

Robinson, C. D., Lee, M. G., Dearing, E., \& Rogers, T. (2018). Reducing student absenteeism in the early grades by targeting parental beliefs. American Educational Research Journal, 55(6), 1163-1192. https://doi.org/10.3102/0002831218772274

Roby, D. E. (2004). Research on school attendance and student achievement: A study of Ohio schools. Educational Research Quarterly, 28(1), 3-14. https://doi.org/10.1017/CBO9781107415324.004

Schwartz, A. E., \& Rothbart, M. W. (2020). Let them eat lunch: The impact of universal free meals on student performance.pdf. Journal of Policy Analysis and Management, 39(2), 376-410. https://doi.org/10.1002/pam.22175

Smythe-Leistico, K., \& Page, L. C. (2018). Connect-text: leveraging text-message communication to mitigate chronic absenteeism and improve parental engagement in the earliest uears of schooling.pdf. Journal of Education for Students Placed at Risk, 23(1-2), 139-152. https://doi.org/10.1080/10824669.2018.1434658 
U.S. Department of Education. (2019). Chronic absenteeism in the nation's schools.

https://www2.ed.gov/datastory/chronicabsenteeism.html 
Table 1. Descriptive statistics of main study variables

\begin{tabular}{lcc} 
& & Mean \\
\hline Latinx & 0.814 & 0.389 \\
White & 0.137 & 0.344 \\
Asian & 0.037 & 0.188 \\
IEP & 0.093 & 0.290 \\
English learner & 0.612 & 0.487 \\
Free or reduced lunch & 0.712 & 0.453 \\
Migrant & 0.143 & 0.350 \\
Homeless & 0.040 & 0.195 \\
Total in-school suspensions & 0.030 & 0.238 \\
Total out-of-school suspensions & 0.036 & 0.240 \\
Referred to juvenile court & 0.003 & 0.056 \\
\hline Observations & & \\
\hline
\end{tabular}


Table 2. Effects of Familiar Faces on Absences

\begin{tabular}{|c|c|c|c|}
\hline & $\begin{array}{l}\text { Percentage of days } \\
\text { absent }\end{array}$ & $\begin{array}{l}\text { Percentage of days } \\
\text { absent (unexcused) }\end{array}$ & $\begin{array}{l}\text { Percentage of days } \\
\text { absent (excused) }\end{array}$ \\
\hline Familiar Faces, $\%$ & $\begin{array}{c}-4.217^{* * *} \\
(0.183)\end{array}$ & $\begin{array}{c}-3.639^{* * *} \\
(0.170)\end{array}$ & $\begin{array}{c}-0.577^{* * *} \\
(0.056)\end{array}$ \\
\hline Latinx peers, $\%$ & $\begin{array}{l}-3.067^{*} \\
(1.420)\end{array}$ & $\begin{array}{c}-5.250^{* * *} \\
(1.315)\end{array}$ & $\begin{array}{c}2.183^{* * *} \\
(0.435)\end{array}$ \\
\hline Asian peers, $\%$ & $\begin{array}{l}4.934^{*} \\
(2.392)\end{array}$ & $\begin{array}{l}5.154^{*} \\
(2.214)\end{array}$ & $\begin{array}{l}-0.220 \\
(0.733)\end{array}$ \\
\hline Peers with IEP, $\%$ & $\begin{array}{c}0.598 \\
(1.853)\end{array}$ & $\begin{array}{l}-0.059 \\
(1.715)\end{array}$ & $\begin{array}{c}0.657 \\
(0.568)\end{array}$ \\
\hline $\begin{array}{l}\text { Peers who are English } \\
\text { learners, \% }\end{array}$ & $\begin{array}{l}-3.245^{* *} \\
(1.053)\end{array}$ & $\begin{array}{l}-2.891^{* *} \\
(0.975)\end{array}$ & $\begin{array}{l}-0.353 \\
(0.323)\end{array}$ \\
\hline $\begin{array}{l}\text { Peers who receive free } \\
\text { or reduced lunch, } \%\end{array}$ & $\begin{array}{l}6.402^{* * * *} \\
(0.921)\end{array}$ & $\begin{array}{l}6.899^{* * * *} \\
(0.853)\end{array}$ & $\begin{array}{l}-0.497 \\
(0.282)\end{array}$ \\
\hline Homeless peers, $\%$ & $\begin{array}{l}-12.487^{* * *} \\
(1.435)\end{array}$ & $\begin{array}{c}-12.367^{* * * *} \\
(1.328)\end{array}$ & $\begin{array}{l}-0.120 \\
(0.440)\end{array}$ \\
\hline Migrant peers, $\%$ & $\begin{array}{l}-6.057^{* * *} \\
(1.151)\end{array}$ & $\begin{array}{l}-5.715^{* * *} \\
(1.065)\end{array}$ & $\begin{array}{l}-0.342 \\
(0.353)\end{array}$ \\
\hline $\begin{array}{l}\text { Peers referred to } \\
\text { juvenile court, \%s }\end{array}$ & $\begin{array}{c}34.701^{* * *} \\
(7.394) \\
\end{array}$ & $\begin{array}{c}27.208^{* * *} \\
(6.846) \\
\end{array}$ & $\begin{array}{l}7.493^{* * * *} \\
(2.267)\end{array}$ \\
\hline Observations & 197567 & 197567 & 197567 \\
\hline
\end{tabular}

Standard errors in parentheses

Models include student and course fixed effects

${ }^{*} p<0.05,{ }^{* *} p<0.01,{ }^{* * *} p<0.001$ 
Table 3. Effects of Familiar Faces on Chronic Absenteeism and Truancy

\begin{tabular}{|c|c|c|c|}
\hline & Chronic absenteeism & Truancy & Chronic truancy \\
\hline Familiar Faces, $\%$ & $\begin{array}{l}-0.033^{*} \\
(0.016)\end{array}$ & $\begin{array}{c}0.014 \\
(0.015)\end{array}$ & $\begin{array}{l}-0.044^{*} \\
(0.018)\end{array}$ \\
\hline Latinx peers, $\%$ & $\begin{array}{l}-0.067 \\
(0.064)\end{array}$ & $\begin{array}{c}0.032 \\
(0.043)\end{array}$ & $\begin{array}{l}-0.099^{*} \\
(0.043)\end{array}$ \\
\hline Asian peers, $\%$ & $\begin{array}{l}-0.042 \\
(0.145)\end{array}$ & $\begin{array}{c}0.044 \\
(0.097)\end{array}$ & $\begin{array}{l}-0.085 \\
(0.099)\end{array}$ \\
\hline Peers with IEP, \% & $\begin{array}{c}0.326^{* * *} \\
(0.043)\end{array}$ & $\begin{array}{c}0.125^{* * *} \\
(0.029)\end{array}$ & $\begin{array}{c}0.201^{* * * *} \\
(0.029)\end{array}$ \\
\hline $\begin{array}{l}\text { Peers who are English } \\
\text { learners, \% }\end{array}$ & $\begin{array}{c}0.112 \\
(0.060)\end{array}$ & $\begin{array}{c}0.004 \\
(0.040)\end{array}$ & $\begin{array}{l}0.109^{* *} \\
(0.041)\end{array}$ \\
\hline $\begin{array}{l}\text { Peers who receive free } \\
\text { or reduced lunch, } \%\end{array}$ & $\begin{array}{l}-0.047 \\
(0.061)\end{array}$ & $\begin{array}{l}-0.011 \\
(0.041)\end{array}$ & $\begin{array}{l}-0.037 \\
(0.041)\end{array}$ \\
\hline Homeless peers, $\%$ & $\begin{array}{c}0.056 \\
(0.115)\end{array}$ & $\begin{array}{l}-0.144 \\
(0.077)\end{array}$ & $\begin{array}{l}0.200^{*} \\
(0.079)\end{array}$ \\
\hline Migrant peers, $\%$ & $\begin{array}{c}0.139 \\
(0.075)\end{array}$ & $\begin{array}{c}0.071 \\
(0.051)\end{array}$ & $\begin{array}{c}0.068 \\
(0.051)\end{array}$ \\
\hline $\begin{array}{l}\text { Peers referred to } \\
\text { juvenile court, } \%\end{array}$ & $\begin{array}{l}-0.413 \\
(0.422) \\
\end{array}$ & $\begin{array}{c}0.243 \\
(0.284) \\
\end{array}$ & $\begin{array}{l}-0.656^{*} \\
(0.288) \\
\end{array}$ \\
\hline Observations & 17465 & 17465 & 17465 \\
\hline
\end{tabular}

Standard errors in parentheses

Models include school, grade, and year fixed effects

${ }^{*} p<0.05,{ }^{* *} p<0.01,{ }^{* * *} p<0.001$ 
Table 4. Effects of Familiar Faces on Absences (by Course Type)

\begin{tabular}{|c|c|c|c|c|c|}
\hline & $\begin{array}{c}\text { Percentage of } \\
\text { days absent } \\
\text { (academic) }\end{array}$ & $\begin{array}{c}\text { Percentage of } \\
\text { days absent } \\
\text { (non-academic) }\end{array}$ & $\begin{array}{c}\text { Percentage of } \\
\text { days absent } \\
\text { (Period 1) }\end{array}$ & $\begin{array}{c}\text { Percentage of } \\
\text { days absent } \\
\text { (Period 7) }\end{array}$ & $\begin{array}{c}\text { Percentage of } \\
\text { days absent } \\
\text { (Periods 2-6) }\end{array}$ \\
\hline Familiar Faces, $\%$ & $\begin{array}{c}-3.489^{* * *} \\
(0.260)\end{array}$ & $\begin{array}{c}-5.261^{* * *} \\
(0.305)\end{array}$ & $\begin{array}{c}-4.554^{* * *} \\
(0.581)\end{array}$ & $\begin{array}{l}-1.210 \\
(1.014)\end{array}$ & $\begin{array}{c}-4.260^{* * * *} \\
(0.211)\end{array}$ \\
\hline Latinx peers, $\%$ & $\begin{array}{l}-2.126 \\
(2.263)\end{array}$ & $\begin{array}{l}-3.884 \\
(2.759)\end{array}$ & $\begin{array}{l}3.635 \\
(6.374)\end{array}$ & $\begin{array}{c}1.542 \\
(5.269)\end{array}$ & $\begin{array}{l}-2.352 \\
(1.875)\end{array}$ \\
\hline Asian peers, $\%$ & $\begin{array}{c}6.853 \\
(3.757)\end{array}$ & $\begin{array}{l}1.342 \\
(4.591)\end{array}$ & $\begin{array}{c}19.980 \\
(10.793)\end{array}$ & $\begin{array}{c}8.451 \\
(7.538)\end{array}$ & $\begin{array}{l}8.005^{*} \\
(3.276)\end{array}$ \\
\hline Peers with IEP, \% & $\begin{array}{l}-4.818 \\
(2.939)\end{array}$ & $\begin{array}{c}10.720^{* * *} \\
(3.746)\end{array}$ & $\begin{array}{l}1.266 \\
(7.205)\end{array}$ & $\begin{array}{l}18.995^{*} \\
(8.850)\end{array}$ & $\begin{array}{l}-3.301 \\
(2.390)\end{array}$ \\
\hline $\begin{array}{l}\text { Peers that are English } \\
\text { learners, } \%\end{array}$ & $\begin{array}{l}-4.456^{* *} \\
(1.637)\end{array}$ & $\begin{array}{l}-2.688 \\
(2.056)\end{array}$ & $\begin{array}{l}-8.190 \\
(4.462)\end{array}$ & $\begin{array}{l}-0.177 \\
(3.693)\end{array}$ & $\begin{array}{l}-3.966^{* *} \\
(1.402)\end{array}$ \\
\hline $\begin{array}{l}\text { Peers that receive free } \\
\text { or reduced lunch, } \%\end{array}$ & $\begin{array}{l}7.595^{* * *} \\
(1.453)\end{array}$ & $\begin{array}{l}6.121^{* * * *} \\
(1.791)\end{array}$ & $\begin{array}{c}1.625 \\
(3.846)\end{array}$ & $\begin{array}{l}3.197 \\
(3.248)\end{array}$ & $\begin{array}{l}8.151^{* * * *} \\
(1.216)\end{array}$ \\
\hline Homeless peers, $\%$ & $\begin{array}{l}-15.444^{* * *} \\
(2.207)\end{array}$ & $\begin{array}{c}-14.434^{* * *} \\
(2.843)\end{array}$ & $\begin{array}{c}-15.484^{* *} \\
(5.138)\end{array}$ & $\begin{array}{c}4.677 \\
(5.591)\end{array}$ & $\begin{array}{c}-14.262^{* * *} \\
(1.782)\end{array}$ \\
\hline Migrant peers, $\%$ & $\begin{array}{c}-8.905^{* * * *} \\
(1.761)\end{array}$ & $\begin{array}{c}-8.588^{* * *} \\
(2.314)\end{array}$ & $\begin{array}{c}-10.640^{*} \\
(4.657)\end{array}$ & $\begin{array}{l}-4.403 \\
(4.235)\end{array}$ & $\begin{array}{c}-8.679^{* * * *} \\
(1.487)\end{array}$ \\
\hline $\begin{array}{l}\text { Peers referred to } \\
\text { juvenile court, \% }\end{array}$ & $\begin{array}{l}43.698^{* * * *} \\
(10.632)\end{array}$ & $\begin{array}{c}-6.193 \\
(16.332)\end{array}$ & $\begin{array}{l}43.836^{*} \\
(18.837)\end{array}$ & $\begin{array}{l}554.282^{* * * *} \\
(96.946)\end{array}$ & $\begin{array}{l}30.850^{* * *} \\
(9.789)\end{array}$ \\
\hline Observations & 111584 & 82481 & 32856 & 10830 & 148313 \\
\hline
\end{tabular}

Standard errors in parentheses

Models include student and course fixed effects

${ }^{*} p<0.05,{ }^{* *} p<0.01,{ }^{* * *} p<0.001$ 
Table 5. Effects of Familiar Faces on Suspensions

\begin{tabular}{|c|c|c|c|}
\hline & Total suspensions & $\begin{array}{l}\text { Total in-school } \\
\text { suspensions }\end{array}$ & $\begin{array}{l}\text { Total out-of-school } \\
\text { suspensions }\end{array}$ \\
\hline Familiar Faces, $\%$ & $\begin{array}{l}-0.006 \\
(0.013)\end{array}$ & $\begin{array}{l}-0.021^{*} \\
(0.009)\end{array}$ & $\begin{array}{c}0.015 \\
(0.009)\end{array}$ \\
\hline Latinx peers, $\%$ & $\begin{array}{l}-0.067 \\
(0.064)\end{array}$ & $\begin{array}{c}0.032 \\
(0.043)\end{array}$ & $\begin{array}{l}-0.099^{*} \\
(0.043)\end{array}$ \\
\hline Asian peers, $\%$ & $\begin{array}{l}-0.042 \\
(0.145)\end{array}$ & $\begin{array}{c}0.044 \\
(0.097)\end{array}$ & $\begin{array}{l}-0.085 \\
(0.099)\end{array}$ \\
\hline Peers with IEP, $\%$ & $\begin{array}{l}0.326^{* * * *} \\
(0.043)\end{array}$ & $\begin{array}{l}0.125^{* * * *} \\
(0.029)\end{array}$ & $\begin{array}{c}0.201^{* * *} \\
(0.029)\end{array}$ \\
\hline $\begin{array}{l}\text { Peers who are English } \\
\text { learners, } \%\end{array}$ & $\begin{array}{c}0.112 \\
(0.060)\end{array}$ & $\begin{array}{c}0.004 \\
(0.040)\end{array}$ & $\begin{array}{l}0.109^{* *} \\
(0.041)\end{array}$ \\
\hline $\begin{array}{l}\text { Peers who receive free } \\
\text { or reduced lunch, } \%\end{array}$ & $\begin{array}{l}-0.047 \\
(0.061)\end{array}$ & $\begin{array}{l}-0.011 \\
(0.041)\end{array}$ & $\begin{array}{l}-0.037 \\
(0.041)\end{array}$ \\
\hline Homeless peers, $\%$ & $\begin{array}{l}0.056 \\
(0.115)\end{array}$ & $\begin{array}{l}-0.144 \\
(0.077)\end{array}$ & $\begin{array}{l}0.200^{*} \\
(0.079)\end{array}$ \\
\hline Migrant peers, $\%$ & $\begin{array}{c}0.139 \\
(0.075)\end{array}$ & $\begin{array}{c}0.071 \\
(0.051)\end{array}$ & $\begin{array}{c}0.068 \\
(0.051)\end{array}$ \\
\hline $\begin{array}{l}\text { Peers referred to } \\
\text { juvenile court, } \%\end{array}$ & $\begin{array}{l}-0.413 \\
(0.422) \\
\end{array}$ & $\begin{array}{c}0.243 \\
(0.284) \\
\end{array}$ & $\begin{array}{l}-0.656^{*} \\
(0.288) \\
\end{array}$ \\
\hline Observations & 17465 & 17465 & 17465 \\
\hline
\end{tabular}

Standard errors in parentheses

Models include school, grade, and year fixed effects ${ }^{*} p<0.05,{ }^{* *} p<0.01,{ }^{* * *} p<0.001$ 